\title{
Does the contribution of women to household expenditure explain contraceptive use? An assessment of the relevance of bargaining theory to Africa
}

\author{
Ayaga A. Bawah ${ }^{1},{ }^{\text {i }}$ Patrick O. Asuming ${ }^{1}$, Martin Bangha ${ }^{2}$, James F. Phillips ${ }^{1}$ \\ and Maya Vaughan-Smith ${ }^{3}$ \\ ${ }^{1}$ Heilbrunn Department of Population and Family Health, Columbia University \\ 60 Haven Avenue, New York 10032, USA \\ ${ }^{2}$ INDEPTH Network, P.O. Box KD213, Accra, Ghana \\ ${ }^{3}$ Department of Anthropology, Brown University, Providence, RI, USA
}

\begin{abstract}
This paper draws on the concept of bargaining theory to interpret contraceptive decision-making among women who express a desire to limit or space children. Bargaining theory assumes conflict in decision making within households and posits that such conflict is resolved through bargaining. Women's bargaining power is said to increase with more control of resources. The underlying assumption is that household decisions are governed by economics. This paper acknowledges that economics may influence reproductive decisions, but posits that African social norms and institutions are more important in defining conjugal roles than spousal relative economic contribution to family expenditure. Findings from seven African countries show that women who contribute more income to household expenditure are no more likely to adopt family planning as predicted by bargaining theory. These results bring into question theoretical perspectives that are sometimes promoted as generic explanatory models without validation in specific cultural settings.
\end{abstract}

Keywords: Family planning, bargaining theory, decision-making, empowerment, contraceptive use

\section{Résumé}

Cet article se sert du concept de la théorie de négociation pour interpréter la prise de décision contraceptive parmi les femmes qui expriment le désir de limiter ou d'espacer les naissances. La théorie de négociation suppose qu'il y'a le conflit dans la prise de décision dans des ménages et avance qu'en principe ce conflit est souvent résolu par la négociation. En général, il est affirmé que le pouvoir de la négociation des femmes augmente au fur et à mesure qu'elles ont plus des ressources à leurs dispositions. L'hypothèse fondamentale est que des décisions de ménage sont régies par des forces des marchés. Cet article reconnaît que les forces du marchés peuvent influencer des décisions relative a la procréation, mais avance aussi qu'en principe les normes et les établissements sociaux africains sont plus importants dans la définition des rôles conjugaux que la contribution économique des épouses à la dépense de la famille. Les résultats basés sur les donnés de sept pays africains montrent que les femmes qui contribuent plus de revenu aux dépenses de leur ménage n'ont pas plus de tendances a adopter la planification familiale comme prévues par la théorie de négociation. Ces résultats mettre en questions les perspectives théoriques qui sont parfois favorisées en tant que modèles génériques explicatifs sans validation dans les milieux culturels spécifiques.

Mots clés: Planification familiale, théorie de négociation, prise de décision, émancipation, utilisation contraceptive

\section{Introduction}

This paper draws on the concept of bargaining theory to interpret contraceptive decision-making among currently married women who express a desire to limit or space children. Con-

i. Bawah, Ayaga A. <aab2161@cumc.columbia.edu> traceptive use rates remain relatively low in Africa despite increased awareness among the population of the availability of various modern methods of contraception. In Ghana, for example, data from the 1993 Demographic and Health Survey (DHS) showed that about 90.7 
percent of married women knew at least one method of modern contraception in 1993, but that only 10.1 percent were using modern contraceptives (Ghana Statistical Services and Macro International Inc. 1994). Subsequent DHS surveys reported a modest increase in use to about 13.3 percent and 24.2 percent in 1998 and 2003, respectively (Ghana Statistical Services and Macro International Inc., 1999; 2004). The 2008 DHS report for Ghana showed a slight reduction in modern contraceptive use (Ghana Statistical Services and Macro International Inc. 2009). This observation is similar across many African countries; in Uganda in 1996, while 97.4 percent of married women reported knowledge of a modern method of contraception, only a mere 17.9 percent were currently using any modern method of contraception. Similar observations are made for Kenya ( 96.4 knowledge of modern methods in the most recent DHS - 2008/9 - compared to 28.0 percent currently using them); and Namibia (99.1 percent knew at least one modern method of contraception but 53.4 of married women reported in 2006 that they were using a method. Similar observations are made for Mali and Burkina Faso, both included in the current analyses.

The slow adoption of family planning in Africa despite almost universal knowledge of prevalent contraceptive commodities calls to question the success of the family planning programmes in sub-Saharan Africa. Several factors are reported as accounting for the slow pace of adoption of contraceptive use in Africa, including traditions that promote deep-seated resistance to family planning (Bawah et al. 1999; Rutenberg et al. 1997; Hulton et al. 2000), low female education (Martin 1995; Ainsworth, Beeble and Nyamete 1996; Cleland, Ndugwa and Zulu 20II), and failed family planning policies (National Research Council 1993; Cleland, Ndugwa and Zulu 20I I).

Although DHS results from various African countries show wide variations in contraceptive use rates, countries in Western Africa tend have much lower contraception adoption rates compared to those of Eastern and Southern Africa (Cleland, Ndugwa and Zulu 20II). Adoption patterns also vary by gender, with men often reporting more use than women, perhaps owing to multiple partner use. Differences in gender adoption rates may also result from different motivations with regard to men and women. Explanations given for the differences between husbands and wives focus on their different conjugal responsibilities with regard to child bearing and rearing and the social determinants of demand for children. Although women bear the burden of childbirth and care and tend to want fewer children than men, their demand for contraception often remains latent because of spousal opposition to fertility regulation (Fapohunda and Rutenberg 1999; Bawah et al. 1999; Blanc 200I).

Two schools of thought have emerged to explain the discrepant reproductive aspirations of husbands and wives and the persistence of low contraceptive use and high fertility in subSaharan Africa. Sociological explanations are grounded in notions of the determinants and consequences of marriage and family building, polygyny and religious traditions (Caldwell and Caldwell 1990). In this perspective, household economics are acknowledged to be important, but economic influences are linked to intergenerational wealth flows or to the consequences of agricultural practices and the economic value of children to the extended family (Caldwell 1983). A widely accepted, but seldom tested, alternative view emphasizes household economic theory as the dominant framework for reproductive decision-making within households (Rosenzweig 1990). The household model assumes that members agree to certain household management rules about the distribution of resources, including decision-making. Termed the "New Home Economics" model, this perspective assumes that behavior is altruistic and that household members cooperate in the interest of the general good of all (Becker 1965 1973).

Elaborations of Becker's theory are noteworthy. For example, a widely cited perspective argues that household decisions are based on individual tastes and interests (Blood and Wolfe 1960; Folbre 1984; Messer 1990; Engle 1990). Bargaining models emphasize conflict among family members and see resolution of such conflicts through a bargaining process (Blood and Wolfe 1960; Folbre 1984; Messer 1990; Engle 1990; Tabitha et al. 2003; Lundberg and Pollak 1993). According to Folbre (1984) households are constituted by a group of maximizing indi- 
viduals in which members cooperate and bargain with a view to optimizing their personal interests. Bargaining power is thus affected by the ability of individuals to contribute to the household income through extra-familial sources. Other factors that enhance the bargaining power of especially women include school attainment (Caldwell et al. 1992), support from the family of origin, the socio-cultural stratification of roles, as well as the individual's skills or ability at bargaining (Blood and Wolfe 1960; Bennett 1990). Other authors have emphasized the role of culture in defining household bargaining power and decision-making processes (Conklin 1979; Strauss 1977).

This paper tests the hypothesis that relative economic status of women in households explains contraceptive use in seven African countries. Within the context of this framework, we would expect women who contribute more resources to household expenditure to have a greater say in the household decisionmaking process, including demand for fertility regulation. The underlying assumption is that women who contribute more income or resources to the household are likely to wield more power in the household than those who contribute little or none at all, with relative authority translating into reproductive autonomy for women who are empowered to implement their preferences. Other sources of women's power may include having higher education, working outside the home, or having access to extrafamilial connections. The logic of this argument suggests that women with more income relative to their husbands or those who contribute more resources have a higher "threat point" of bargaining. The "threat point" defines the point at which the woman is willing to risk spousal conflict when bargaining with her husband.

\section{Is "bargaining theory" relevant to the African context?}

Bargaining theory as it is conventionally conceptualized may not be relevant to sub-Saharan Africa. Bargaining theory is premised on the assumption that household decisions are governed by economics and that the more resources one contributes to the household, the more power one is likely to wield. However, relative power may be defined by social institutions that are unrelated to such contributions. Moreover, bargaining theory implicitly assumes that all decisions within the household are solely taken by the conjugal partners and governed by their collective and individual preferences and ultimately by the superior strength of the dominant partner defined by resources. While this may be true in some cultural contexts, such notions may be alien to the sub-Saharan African context where marriage is constituted within patriarchy that tends to define roles between men and women. For instance, in many settings in sub-Saharan Africa, reproductive decisions may not be entirely governed by economics or may not be jointly taken. As Fapohunda and Todaro (1988) noted of West Africa, “... spouses do not necessarily follow joint household financial management practices." For example, the decision to use or not use contraception may or may not be jointly taken by a couple. Reproductive decisions are sometimes governed by social norms and institutions, which often give priority to the views and opinions of men (National Research Council 1993), even if their contribution to the household expenditure or maintenance of the family is less than those of their wives. Also, because the marriage contract involves the payment of bride wealth, which in some sense constitutes compensation to the bride's family for her upbringing and also for future children, reproductive decision-making is indirectly transferred to the male side (Caldwell and Caldwell 1990; Dodoo and Landewijk 1996). Thus, although a woman may contribute more than her husband to the household expenditure, decisions regarding her reproductive desires may still be subjugated to those of her husband.

Moreover, some women may seek to fulfil their reproductive aspirations with strategies that are independent of the preferences of their husbands, leading in some instances to covert contraceptive use that would be opposed by a husband and his extended family if this practice were known (Biddlecom and Fapohunda 1998; Bawah et al. 1999; Woodsong 2004). It is plausible that women who want to control their reproduction and have the resources to afford the cost of adopting a contraceptive method without the support of their husbands or even their knowledge would do so. Under such cir- 
cumstances, women who have personal sources of income may be in a better position to implement their reproductive goals through covert use of contraception relative to women who lack the means to purchase contraceptives supplies. Thus if a woman retains a greater proportion of her earnings for personal use, then she is in a better position to adopt contraception than a woman who has no income at all, or one who commits most of her income to household expenditures.

We argue that merely contributing more income to the household budget does not necessarily empower women to take contraceptive decisions. Rather, cultural influences such as male preference for additional children and religion are important determinants of contraceptive use. Contraceptive use by women can precipitate spousal discord (Bawah et al. 1999). Women who earn income and are able to save a greater portion of that income for their personal use are in a better position to mitigate the social, familial, and spousal costs of contraception.

\section{Data and methods}

DHS data from seven countries are used to test the hypothesis that bargaining power affects contraceptive use from seven African countries: Burkina Faso (2003; 2008), Ghana (2003; 2008), Kenya (2003; 2008), Mali (200 I; 2006), Mozambique $(2003 ; 2008)$, Namibia $(2000 ; 2006-7)$ and Uganda (2000; 2006). The DHSs are nationally representative surveys of women age 15-49 and men age 15-59. The DHS surveys use standard model questionnaires to collect comparable information on demographic characteristics of respondents, their reproductive statuses and intentions, breast-feeding practices, contraceptive use (both current and past), and a series of KAP-type (Knowledge, Attitudes and Practice) survey questions. Information is also collected on economic activities, including men and women's work.

The choice of countries was informed by whether or not the question from which the key independent variable is derived was included in the country's instrument. However, the countries used here represent a good spread in terms of geographic region, level of development and cultural diversity of sub-Saharan Africa.

Respondents were asked to indicate how much of their income (cash or kind) they contribute to the expenditure of their household. Response categories included "Almost none", "Less than half", "About half", "All”, and "None, her income is all saved." We define a three-category variable from these responses representing the proportion of income women contribute to the expenditure of their households: "none, income saved", "less than half" and "more than half". Since the outcome variable (an indicator for use of contraceptives) is dichotomous, we use a maximum likelihood logistic regression. Other variables to capture cultural influences are religion and relative preference of males for additional children.

We also include controls for differences in ethnic background and region of residence to capture possible differences in the supply of contraceptives. The other variables in the model are husband's and wife's education, age of the women, place of residence (rural/urban), whether or not women current has more or less children than her ideal number. Finally, to adjust for relative household income, a principal component scale was estimated from poverty indicators to develop quintiles that are employed as independent variables. Unmarried women and women who were married, but temporarily separated from their husbands are excluded from the analysis. Women who indicated that they are infecund are also excluded from the analysis since they are unlikely to use contraceptives for fertility control. 


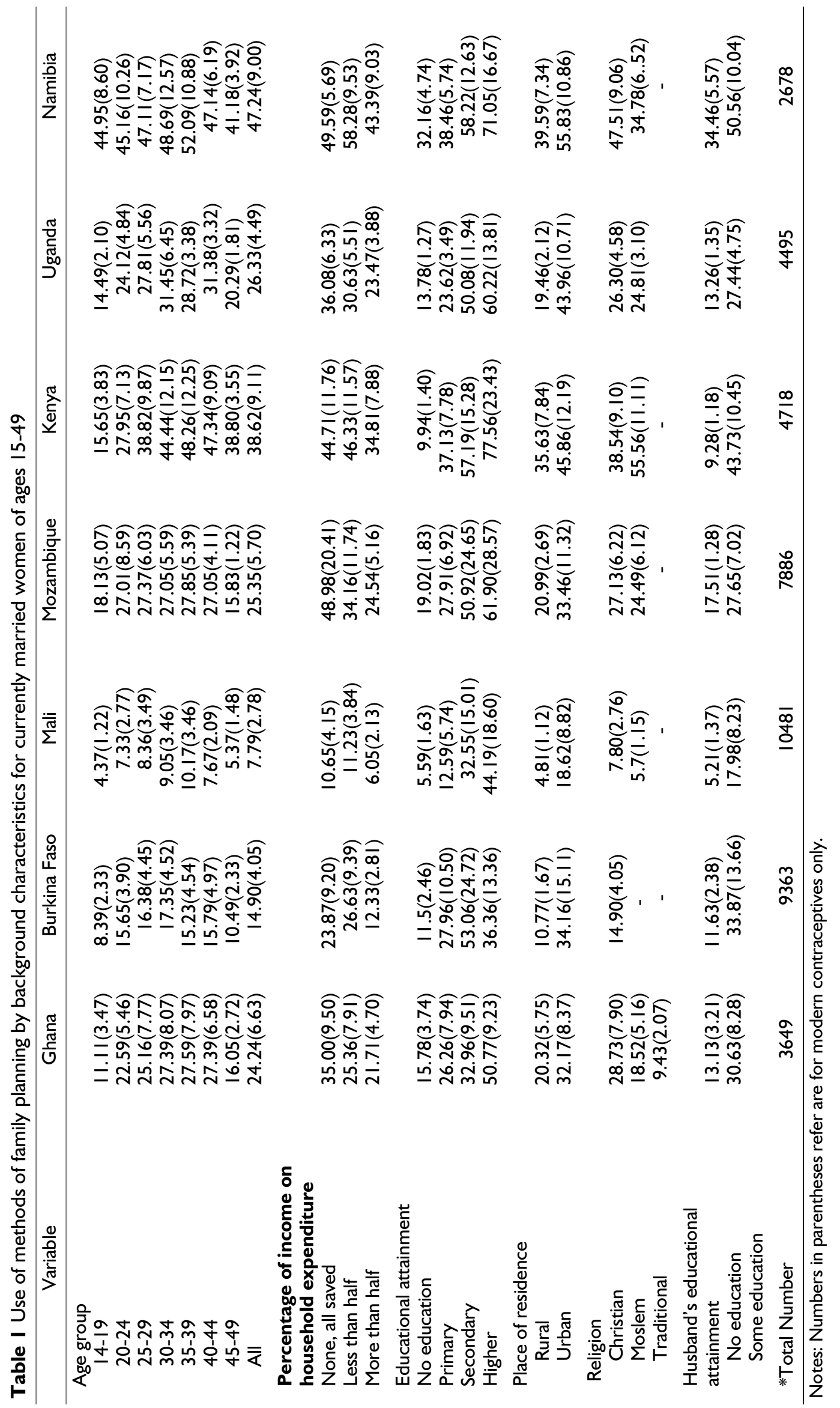




\section{Data limitations}

Table 2 Reasons for non-use of contraceptives among non-users and contraceptive decision-making in household

\begin{tabular}{|c|c|c|c|c|c|c|c|}
\hline & Ghana & $\begin{array}{l}\text { Burkina Kenya } \\
\text { Faso }\end{array}$ & Mali & \multicolumn{2}{|c|}{ Mozambique } & Namibia & Uganda \\
\hline \multicolumn{8}{|c|}{ Panel A: Reasons for not currently using any contraceptive method (percent of non-users) } \\
\hline Not married & 0.26 & - & - & 0.09 & 0.06 & - & - \\
\hline Infrequent sex & 6.75 & 11.08 & 3.99 & 4.26 & 4.40 & 4.09 & 5.80 \\
\hline Menopausal, hyster & 7.00 & 8.61 & 6.68 & 3.24 & 2.94 & 16.54 & 5.45 \\
\hline Subfecund/infecund & 13.75 & 11.60 & 10.82 & 5.87 & 16.18 & 12.45 & 19.24 \\
\hline Want more children & 14.77 & 18.68 & 15.43 & 17.59 & 48.14 & 22.37 & 9.84 \\
\hline Opposed to it & 5.21 & 5.78 & 9.06 & 21.12 & 6.00 & 12.45 & 3.78 \\
\hline Opposed by husband & 3.84 & 8.85 & 5.76 & 8.67 & 4.50 & 4.67 & 9.75 \\
\hline Opposed by others & 0.09 & 0.10 & 0.38 & 0.11 & 0.06 & 0.19 & 0.18 \\
\hline Religion prohibits & 4.01 & 3.17 & 24.33 & 6.13 & 1.31 & 3.89 & 4.04 \\
\hline Knows no method & 5.55 & 5.64 & 2.30 & 12.18 & 5.12 & 5.64 & 6.33 \\
\hline Knows no source & 2.48 & 11.71 & 0.77 & 5.44 & 1.87 & 0.58 & 3.43 \\
\hline Health concerns & 7.51 & 3.52 & 7.06 & 5.55 & 2.25 & 11.09 & 6.85 \\
\hline Fear side effects & 24.25 & 5.75 & 11.74 & 3.41 & 2.19 & 2.92 & 18.80 \\
\hline Lack of access & 0.77 & 0.66 & 0.31 & 0.61 & 0.78 & 0.78 & 1.05 \\
\hline Costs too much & 1.37 & 3.45 & - & 1.26 & 0.19 & 0.58 & 1.93 \\
\hline Inconvenient to use & 0.85 & 0.45 & 0.23 & 0.56 & 2.81 & - & 1.05 \\
\hline Inconvenient to body & 1.51 & 0.94 & 1.15 & 3.83 & 1.19 & 1.75 & 2.46 \\
\hline No of respondents & 1,171 & 2,870 & 1,303 & 5,402 & 3201 & 514 & 1138 \\
\hline \multicolumn{8}{|c|}{ Panel B: Decision-maker on contraceptives $(\% \text { of respondents })^{a}$} \\
\hline Mainly woman & 15.60 & 37.13 & 29.18 & 43.81 & 24.20 & & 37.76 \\
\hline Mainly partner & 11.82 & 10.59 & 10.59 & 19.30 & 10.87 & & 11.65 \\
\hline Joint decision & 72.10 & 51.99 & 59.24 & 25.42 & 63.31 & & 46.85 \\
\hline Other & 0.47 & 0.29 & 0.99 & 11.47 & 1.62 & & - \\
\hline No of respondents & 846 & 1360 & 1813 & 767 & 2033 & & 1176 \\
\hline
\end{tabular}

a: this information is not available for Namibia

Examining the direct effect of relative income of men to women's income on contraceptive use would constitute a more rigorous test of the bargaining hypothesis than models estimated in this analysis. DHS surveys do not collect information on actual income levels for respondents. We have therefore used women's contribution to household expenditure as a proxy indicator of relative bargaining power. This variable is widely used as an indicator of the measure of women's empowerment (Hoddinott and Haddad 1995; Blumberg 1988). Also, note that the latter rounds of DHS did not collect information on contribution of women's expenditure to the household so we did not include the latter rounds of DHS data beyond the early 1990 rounds in our primary measure that represents relative bargaining power. However, there were other variables that were collected in the latter rounds of the DHS that we thought could be used as proxies for relative bargaining power (e.g. women's employment and earning of income) that we subsequently used and reported the results in the appendixes. Using those measure did not, however, alter the conclusions in any way.

\section{Descriptive statistics}

Table I shows current contraceptive use (all forms) by background characteristics for all countries. Current use of modern contraceptive methods is also reported in brackets. There is a wide variation in use of family planning methods among the countries, ranging from $7.8 \%$ in Mali to $47.2 \%$ in Namibia. Traditional methods of contraception are more popular than modern methods as the inclusion traditional methods markedly increase contraceptive use rates. 
There is an inverted- $U$ relationship between contraceptive usage and age, with the highest rates occurring among 30-39 year-olds. Use rates also vary by education, religion and place of residence. Women who have some form of education are more likely to practise family planning than those without any form of education at all. For all countries except Burkina Faso, the likelihood of contraceptive use progressively increases with levels of education. Usage rates are also higher for women whose partners have some education compared to those whose partners have no education. The likelihood of use also differs by religion. In Ghana, Mali, Mozambique and Namibia Christians are more likely to use contraceptives than Moslems, while the opposite is the case in Kenya and Uganda.

Contrary to the prediction of a bargaining model, women who retain their income for personal use are not more likely to practise family planning compared to those who report that they contribute a share of their earned income to the household expenditure. In Ghana, Mozambique and Uganda use rates fall monotonically as women contribute a greater share of their income to household expenditure. In the other countries, use rates rise marginally when women contribute less than half of their income but falls sharply when they contribute more than half of their income to household expenditure.

Panel B of Table 2 shows that for most of the countries decisions about contraceptive use is a joint decision involving both partners. Panel $A$ of Table 2 presents reasons for non-use of any family planning method. As expected, the most common reasons that married women do not currently use any contraceptive method (see table 2) are infecundity, menopause and desire for more children. In the regressions, we include an indicator for whether a women's current number of children is more or less than her desired number of children. The table also shows that cost of contraception is not a major reason for non-use. Fear of side-effects and health concerns related to contraceptives remain significant reasons for non-use. Almost a quarter $(24.3 \%)$ of non-users in Ghana, $11.7 \%$ in Kenya and $18.8 \%$ in Namibia cite fear of sideeffects while $7.5 \%$ of non-users in Ghana, $7.1 \%$ in Kenya, II.I\% in Namibia and $6.7 \%$ in Uganda cite health concerns. Opposition by husbands is prominent in Burkina Faso (8.9\%), Mali (8.7\%) and Uganda (9.8\%). Other reasons for non-use include lack of knowledge on sources and methods and infrequent sexual activity.

\section{Regression results}

Table 3 presents logistic regression odds ratios estimating the gross and net effects of the proportion of women's income contribution to the household expenditure on their likelihood of contraceptive use controlling for women, their partner and household characteristics. Also included in the regressions are variables that capture the effect of cultural influences on fertility control. All the regressions reported in this table include controls for region of residence and both wife and husband's occupation.

The results do not support the core hypothesis of bargaining theory that women who contribute disproportionally more resources to household expenditures are empowered to take contraceptive decisions. For almost all countries except Ghana there are no statistically significant differences in the likelihood of using a contraceptive among women who contribute contrasting fractions of their income to household expenditures. In fact, in the case of Ghana, women who contribute more than half of their income are significantly less likely to use contraceptives relative to those who contribute nothing.

In the latter round of the DHS there was a question that captures women's earnings from employment which we again used, comparing her earnings with that of her husband. We constructed a three category variable in a similar fashion as in the case of relative contribution to the household budget (Same as husband, More than husband and Less than husband). Again, the argument is that if the woman's earning from her employment is more than that of her husband, she is likely to have a stronger bargaining power to be able to implement her reproductive decisions. As before, results from this measure do not support the hypothesis (reported in Appendix Table A). Along similar lines of reasoning, we examined further earnings from employment where the woman reports that she is paid in cash. These results are reported in Appendix Table B. 
Table 3 Logistic regression results predicting contraceptive use as a function of women's contribution to household expenditure controlling for background characteristics

\begin{tabular}{|c|c|c|c|c|c|c|c|}
\hline Variable & Ghana & $\begin{array}{l}\text { Burkina } \\
\text { Faso }\end{array}$ & Mali & Kenya & $\begin{array}{l}\text { Mozam- } \\
\text { bique }\end{array}$ & Uganda & Namibia \\
\hline \multicolumn{8}{|c|}{ Contribution of woman's income to household expenditure: } \\
\hline None, income saved (Ref) & 1.000 & 1.000 & 1.000 & 1.000 & 1.000 & 1.000 & 1.000 \\
\hline Some, but less than half & $0.637^{* *}$ & 1.037 & 0.938 & 0.928 & 0.706 & 1.233 & 1.204 \\
\hline More than half & $0.619 * * *$ & 0.898 & 0.749 & 0.993 & 0.788 & 1.357 & 0.999 \\
\hline \multicolumn{8}{|l|}{ Education } \\
\hline No education (ref) & 1.000 & 1.000 & 1.000 & 1.000 & 1.000 & 1.000 & 1.000 \\
\hline Primary & I.362** & $1.502 * * * *$ & 1.294 & $2.960 * * * *$ & 1.316 **** & I.528**** & 1.166 \\
\hline Secondary & I.602**** & $2.546 * * * *$ & $2.312 * * * *$ & $5.531^{* * * *}$ & I.846**** & $2.401 * * * *$ & $2.082 * * *$ \\
\hline Higher & $2.000 *$ & 1.016 & 1.738 & II.455** & 1.615 & $2.750 * * * *$ & $2.769 * * *$ \\
\hline \multicolumn{8}{|l|}{ Wife's age } \\
\hline $15-19$ (ref) & 1.000 & 1.000 & 1.000 & 1.000 & 1.000 & 1.000 & 1.000 \\
\hline $20-29$ & 1.636 & $\mathrm{I} .85 \mathrm{I} * * *$ & I.987**** & $1.643^{* *}$ & I.498**** & 1.166 & 0.993 \\
\hline $30-39$ & $1.65 \mathrm{I}$ & I.7I $7 * * * *$ & 2.017 ***** & I.756**** & 1.126 & 1.134 & 1.080 \\
\hline $40-49$ & 0.834 & I.473* & $1.45 \mathrm{I}$ & 1.160 & $0.668 * *$ & 0.831 & 0.605 \\
\hline \multicolumn{8}{|l|}{ Place of residence } \\
\hline Urban (Ref) & 1.000 & 1.000 & 1.000 & 1.000 & 1.000 & 1.000 & 1.000 \\
\hline Rural & $\mathrm{I} .047$ & $0.626 * * * *$ & $0.652 * *$ & 0.984 & 1.151 & 0.886 & 1.050 \\
\hline \multicolumn{8}{|l|}{ Religion } \\
\hline Christianity (Ref) & 1.000 & - & 1.000 & 1.000 & 1.000 & 1.000 & 1.000 \\
\hline Islam & $0.773 *$ & - & 0.751 & 1.345 & 1.036 & $1.40 \mathrm{I}$ & $0.459 *$ \\
\hline Traditional & $0.463 * * * *$ & - & - & - & - & - & - \\
\hline \multicolumn{8}{|l|}{ Type of marriage } \\
\hline Monogamous (Ref) & 1.000 & 1.000 & 1.000 & 1.000 & 1.000 & 1.000 & 1.000 \\
\hline Polygamous & 0.943 & $0.663^{* * * *}$ & $0.756 * *$ & 0.914 & $0.848^{*}$ & 1.048 & 0.957 \\
\hline \multicolumn{8}{|l|}{ Household poverty quintile } \\
\hline Poorest quintile (Ref) & 1.000 & 1.000 & 1.000 & 1.000 & 1.000 & 1.000 & 1.000 \\
\hline $2^{\text {nd }}$ quintile & 1.037 & 1.227 & I.37| & I.263* & 0.982 & I.668*** & 1.086 \\
\hline $3^{\text {rd }}$ quintile & I.204 & 1.228 & I.I 79 & I.I 77 & 1.119 & I. $478^{* * *}$ & 0.943 \\
\hline $4^{\text {th }}$ quintile & 1.163 & $1.32 I^{*}$ & 1.108 & I.726***** & I.333* & 2.356 **** & I.554* \\
\hline $5^{\text {th }}$ quintile & 1.322 & $2.255^{* * * *}$ & $2.25 I^{* * * *}$ & $2.028 * * * *$ & $2.179 * * *$ & $2.894^{* * * *}$ & $\left.1.96\right|^{* * *}$ \\
\hline \multicolumn{8}{|l|}{ Relative fertility preference } \\
\hline Want same no. of children (ref) & 1.000 & 1.000 & 1.000 & 1.000 & 1.000 & 1.000 & 1.000 \\
\hline Husband wants more & $0.795 *$ & $0.593 * * * *$ & $0.787^{* *}$ & $0.670 * * * *$ & $0.815^{* *}$ & $0.658 * * *$ & 0.943 \\
\hline Husband wants less & 0.976 & $1.660 * * *$ & 1.108 & 1.000 & 0.983 & 0.942 & 0.760 \\
\hline \multicolumn{8}{|c|}{ Current number of children of woman } \\
\hline More than desired (ref) & 1.000 & 1.000 & 1.000 & 1.000 & 1.000 & 1.000 & 1.000 \\
\hline Same or less than desired & $\left.0.49\right|^{* * * * *}$ & $0.659 * * *$ & $0.565^{* * * *}$ & $0.71 I^{* * * *}$ & $0.497^{* * * *}$ & $0.55 I^{* * * *}$ & $0.459 * * *$ \\
\hline \multicolumn{8}{|l|}{ Other controls } \\
\hline Region of residence & Yes & Yes & Yes & Yes & Yes & Yes & Yes \\
\hline Wife's occupation & Yes & Yes & Yes & Yes & Yes & Yes & Yes \\
\hline Husband's occupation & Yes & Yes & Yes & Yes & Yes & Yes & Yes \\
\hline \multicolumn{8}{|c|}{ Summary statistics: } \\
\hline Number of observations & 2387 & 4424 & 4107 & 2966 & 3418 & 2104 & 1502 \\
\hline Log Likelihood & -1308.56 & -1688.97 & -1268.67 & -1672.25 & -1932.34 & -1158.14 & -895.39 \\
\hline Pseudo $\mathrm{R}^{2}$ & 0.0819 & 0.1696 & 0.1503 & 0.1836 & 0.1001 & 0.1360 & 0.1329 \\
\hline Wald Chi-square & 204.97 & 597.54 & 429.57 & 515.36 & 381.67 & 299.96 & 231.15 \\
\hline$\%$ correctly predicted & $71.55 \%$ & $82.59 \%$ & $88.14 \%$ & $70.90 \%$ & $70.19 \%$ & $73.24 \%$ & $67.64 \%$ \\
\hline
\end{tabular}


Here again, there is no evidence that if a woman earns cash from employment she is more likely to have the "power" to use contraception. Indeed, we find that in Uganda and Namibia the reverse is the case, where women who are not paid in cash have significantly higher odds of using contraceptive relative to those who report that they are paid cash from employment.

However, what is consistent across all seven countries where the needed variables were collected is the pervasive role of women's education. In all models, women's education is consistently associated with significantly higher use of contraceptives, controlling for a battery of variables.

The education effect is observed at all levels except in a few cases where primary education does not seem to matter (Namibia). Also, in the case of Burkina Faso and Mali, women's education beyond secondary level does not significantly increase use (signs in right direction, nonetheless). Perhaps, this finding has to do with the fact that levels of education in both Burkina Faso and Mali are generally low, such that very few women even earn education beyond secondary level.

In relation to household wealth, differences in contraceptive use exist largely between the extreme rich and extreme poor. The exceptions are Ghana and Uganda. In Ghana, relative household wealth has no impact on the likelihood of contraceptive use. In Uganda, relatively wealthy households are monotonically more likely to use contraceptives.

Our interpretation of the education and income results (bearing in mind that cost is not a factor in the decision to use contraceptives) is that effect of education on contraceptive use probably operates through the knowledge channel rather than the income channel and that adequate knowledge about contraception, especially modern methods, are acquired at the higher levels of education and that only relatively wealthy households can afford these levels of education to obtain this knowledge.

Compared to urban areas, the odds of use are significantly lower in rural areas in Burkina Faso, Mali and Uganda but no differences are found for other countries. There are conflicting findings on the effect of religion on contraceptive use. In Ghana, Muslims and traditional worshippers have lower odds of contraceptive use compared to Christians, but in Uganda Muslims are significantly more likely to use contraceptive compared to Christians. There are no significant differences in use by religion in the other countries. As expected, women who desire more children than they currently have significantly lower the odds of contraceptive use.

\section{Discussion and conclusion}

The analysis has tested the hypothesis that women who contribute more resources to the family budget are more likely to use contraceptives because of enhanced chances of negotiating decisions with their husbands. The reasoning is that such women would have more leveraging in terms of better negotiating familial decisionmaking because of their relative economic power. In other words, they will have higher bargaining power within the household in terms of decision-making, including those relative to reproductive choices. Our analysis attempted to test the relevance of bargaining theory within the context of sub-Saharan Africa. Contrary to expectations derived from bargaining theory, our findings from seven countries in the subregion suggest that women who contribute a greater share of income to household expenditure or even earn more income than their husbands are no more empowered to make family planning decisions than those who contribute nothing. In other words, household decisionmaking and in this particular case the decision to use or not to use contraceptives is not necessarily governed by economics.

However, what is not in doubt is the role of education. Consistently, the results point to the fact that when women are educated, they are more likely to use contraceptives compared to those who are not educated. What this suggests is that education provides individuals with the tools and knowledge to make choices that they believe will advance their course. To put it more bluntly, it appears education is perhaps a better tool of empowerment than the dynamics of household economics. This is because education equips women with more knowledge that allows them to make rational choices including decisions related to the use of contraception.

Also, we believe that decision-making within households is much more nuanced than just economic autonomy. In contrast to notions that 
when women control more resources than their husbands they are more likely to dominate in household decision-making, we argue that African social norms and institutions that define roles for males and females within marriage have significant influences on household decision making processes including contraceptive use (Caldwell and Caldwell 1987). Indeed, this is consistent with sociological theories linking behavior to African social norms and institutions that do not conform to Western household economic theory.

Our results are by no means conclusive on the determinants of women's decision-making on contraceptive use or intra-household family planning decision-making dynamics in the subregion. However, our results support recent empirical research that suggest that attention be paid to cultural factors in modeling household decisions about contraceptive use and fertility preferences and outcomes in developing countries (Rasul 2008). Our results also bring into question theoretical perspectives that are sometimes promoted as generic explanatory models without validation in specific cultural settings. Tabitha et al. (2003) came to a similar conclusion when they tested bargaining theory to female participation in agricultural household decision-making in Kenya when they noted "... our findings demonstrate that variables generally accepted and expected to empower women may apply to some regions of the world but not to others." These findings suggest that policies and programs geared toward promoting family planning should be tailored to the particulars of local cultural norms.

Thus, while the goal of promoting women's livelihoods is certainly laudable and encouraged, it is not necessarily the case that women's economic autonomy will necessarily translate into the power to make household decisions, especially as they relate to reproductive decisionmaking. In other words, efforts toward promoting contraceptive use ought not be focused only on encouraging women's economic empowerment, but rather should be directed toward promoting women's education which is a better empowerment tool and also changes in the sphere of cultural beliefs and norms.

\section{Acknowledgements}

This research was partly supported by grants made to Columbia University by the Hewlett Foundation and the Doris Duke Charitable Foundation.

\section{References}

Bawah, A.A, P. Akweongo, R. Simmons, and J.F. Phillips. 1999. Women's Fears and Men's Anxieties: The impact of family planning on gender relations in northern Ghana" Studies in Family Planning, 30(I): 54-66.

Becker, G.S. 1965. "A theory of the allocation of time." Economic Journal, 75: 493.518.

Becker, G.S. 1973. "A theory of marriage, part I", Journal of Political Economy, 8I: 813-843

Bennet, L. 1990. "An approach to the study of women's productive roles as a determinant of intra-household allocation patterns." in B. Lorge Rogers and N.P. Schlossman (eds). Intra-household Resource Allocation: Issues and Methods for Development Policy and Planning, Helsinki, The United Nations University.

Biddlecom, A.E. and B.M. Fapohunda. 1998. "Covert Contraceptive Use: Prevalence, Motivations and Consequences." Studies in Family Planning, 29 (4): 360-372.

Blanc, A.K. 200I. "The Effect of Power in Sexual Relationships on Sexual and Reproductive Health: An Examination of the Evidence." Studies in Family Planning, 32 (3): 189-213.

Blood, R.O. and Wolfe, D.M. 1960. Husbands and Wives: The Dynamics of Married Living, New York, Free Press

Blumberg, R. L. 1988. "Income under Female verse Male Control: Hypothesis from a

Theory of Gender Stratification and Data from the Third World", Journal of Family Issues, 9: 5I-84.

Caldwell, J.C. 1983. "Direct Economic Costs and Benefits of Children." Pp.458-93. in Determinants of Fertility in Developing Countries, vol.I, edited by: R. Bulatuo and R. Lee. New York: Academic Press.

Caldwell, J.C. and P. Caldwell. 1990. "High Fertility in sub-Saharan Africa." Scientific American 262(5): II8-I25.

Caldwell JC and P Caldwell. 1987. " The cultural context of high fertility in sub-Saharan Africa" Population and Development Review, 13(3):409437

Caldwell, J.C., I.O. Orubuloye and P. Caldwell. 1992. "Fertility Decline in Africa: A New Type of Transition?" Population and Development Review, 18(2): 2 II-242.

Cleland J., R. P. Ndugwa, and E. M. Zulu. 201 I. 
"Family planning in sub-SaharanAfrica: Progress or Stagnation." Bulletin of the World Health Organization 89: 137-143.

Conklin, G.M. 1979. "Cultural determinants of Power for Women in within the Family: A Neglected Aspect of Family Research." Journal of Comparative Family Studies, I (I): 35-53.

Dodoo, F. Nii-Amoo and P. van Landewijk. 1996. "Men, women and the fertility question in subSaharan Africa: an example from Ghana." African Studies Review, 39(3): 29-4I.

Elliot Sober and David Wilson. 1998. "Theories of Motivation", in On to Others: The Evolution and Psychology of Unselfish Behavior, Cambridge: Harvard University Press.

Engle, P.L. 1990. "A theoretical peek into the black box of economic household models." in B. Lorge Rogers and N.P. Schlossman (eds). Intra-household Resource Allocation: Issues and Methods for Development Policy and Planning, Helsinki, The United Nations University.

Fapohunda, B. M. and N. Rutenberg. 1999. Expanding Men's Participation in Reproductive Health. Nairobi: African Population and Policy Research Centre.

Fapohunda, E. and M. Todaro. 1988. "Family structure, Implicit Contracts, and the Demand for Children in Southern Nigeria." Population and Development Review, I4(4): 57I-594.

Folbre, N. 1984. "Household production in the Philippines: a classical approach." Economic Development and Cultural Change, 32(2): 303-330.

Ghana Statistical Service and Macro International Inc. 1994. Ghana Demographic and

Health Survey 1993, Demographic and Health Surveys, Macro International Inc., Calverton , Maryland

Ghana Statistical Service and Macro International Inc. 1999. Ghana Demographic and

Health Survey 1998, Demographic and Health Surveys, Macro International Inc., Calverton , Maryland

Ghana Statistical Service, Noguchi Memorial Institute for Medical Research and ORC Macro. 2004. Ghana Demographic and Health Survey 2003. Calverton, Maryland: GSS, NMIMR, and ORC Macro.

Hoddinott, J. and L. Haddad. 1995. "Does Female Income Influence Household

Expenditure? Evidence from Cote D'lvoire", Oxford Bulletin of Economics and Statistics, 57 (I): 7796.

Hulton LA, Cullen R, and Khalokho SW. 2000. “ Perceptions of the risks of sexual activity and their consequences among Ugandan adolescents.
Studies Family Planning, 31: 35-46

Lundberg, S and Pollak, R. 1993. "Separate spheres bargaining and the marriage market" Journal of Political Economy, 10I (6): 988-1010 (not seen in text)

Ainsworth, M. Beegle, K and N. Andrew. 1996. "The Impact of Women's Schooling on Fertility and Contraceptive Use: A Study of Fourteen SubSaharan African Countries", World Bank Econ Rev

Martin, T.C. 1995. "Women's Education and Fertility: Results from 26 Demographic and

Health Surveys", Studies in Family Planning, 26(4): 187-202

Messer, E. 1990. "Intra-household allocation of resources: perspectives from Anthropology." in B. Lorge Rogers and N.P. Schlossman (eds). Intrahousehold Resource Allocation: Issues and Methods for Development Policy and

Planning, Helsinki, The United Nations University.

National Research Council, 1993. Factors Affecting contraceptive Use in Sub-Saharan Africa. National Academy Press, Washington, DC.

Ngom, P. 1997. "Men's unmet needs for family planning: Implications for African

fertility transitions," Studies in Family Planning 38(3): 192-202. (not seen in text)

Rasul, I. 2008. "Household bargaining over fertility: theory and evidence from Malaysia"

Journal of Development Economics, 86: 2I 5-24I

Rosenzweig, M.R. 1990. "Program interventions, intra-household allocations, and the welfare of individuals: economic models of the household", in B. Lorge Rogers and N.P. Schlossman (eds). Intra-household Resource Allocation: Issues and Methods for Development Policy and Planning, Helsinki, The United Nations University.

Rutenberg $\mathrm{N}$ and Watkins SC. 1997."The buzz outside the clinics: conversations and contraception in Nyanza Province", Kenya. Studies Family Planning ; 28: 290-307

Strauss, M.A. "Exchange and Power in Marriage in Cultural Context: A Multi-method and Multivariate Analysis of Bombay and Minneapolis Families." A paper presented at the 1977 meeting of the Association for Studies, New York.

Tabitha, W.K., Tisdell, C. and K.C. Roy. 2003. "Female Participation in Decision making in Agricultural Households in Kenya: Empirical Findings." International Journal of Agricultural Resources, Governance and Ecology, 2(2): 103-124.

Woodsong, C. 2004. Covert Use of Topical Microbicides: Implications for Acceptability and Use. Perspectives on Sexual and Reproductive Health 36(3): |27-|3|. 
Appendix Table A: Results from latter round of DHS (2008) using relative earnings as measure of bargaining power

\begin{tabular}{|c|c|c|c|c|c|c|c|}
\hline Variable & Ghana & $\begin{array}{c}\text { Burkina } \\
\text { Faso }\end{array}$ & Mali & Kenya & $\begin{array}{c}\text { Mozam- } \\
\text { bique }\end{array}$ & Uganda & Namibia \\
\hline \multicolumn{8}{|c|}{ Woman's earnings from employment } \\
\hline Same as husband (ref) & 1.000 & 1.000 & & 1.000 & 1.000 & 1.000 & 1.000 \\
\hline More than husband & 0.939 & 1.332 & & 0.818 & 0.869 & 0.871 & 0.884 \\
\hline Less than husband & 1.169 & 0.755 & & 0.895 & 0.819 & 1.115 & 1.114 \\
\hline \multicolumn{8}{|l|}{ Woman's education } \\
\hline No education (ref) & 1.000 & 1.000 & & 1.000 & 1.000 & 1.000 & 1.000 \\
\hline Primary & $1.538^{* *}$ & $1.835 * * *$ & & $2.328 * * *$ & 1.289 & $2.333 * * *$ & 1.002 \\
\hline Secondary & I.423* & $2.577^{* * * *}$ & & $3.872 * * *$ & $2.221 * *$ & $3.952 * * *$ & 1.203 \\
\hline Higher & 0.545 & $2.844 * * *$ & & $3.443 * * *$ & $2.375 *$ & $2.206 * * *$ & 1.178 \\
\hline \multicolumn{8}{|l|}{ Woman's age group } \\
\hline $15-19$ (ref) & 1.000 & 1.000 & & 1.000 & 1.000 & 1.000 & 1.000 \\
\hline $20-29$ & 1.703 & $2.973 * * *$ & & $2.748 * *$ & 0.546 & $3.835 * * *$ & 1.049 \\
\hline $30-39$ & 2.005 & 3.611 I*** & & $3.778 * * *$ & 0.580 & $3.612 * * * *$ & 0.775 \\
\hline $40-49$ & 1.284 & $2.542 * * *$ & & 1.794 & $0.274 * * *$ & $5.506 * * *$ & 0.407 \\
\hline \multicolumn{8}{|l|}{ Place of residence } \\
\hline Urban (Ref) & 1.000 & 1.000 & & 1.000 & 1.000 & 1.000 & 1.000 \\
\hline Rural & 1.111 & 0.875 & & 1.159 & 0.851 & $0.525 * *$ & 0.799 \\
\hline \multicolumn{8}{|l|}{ Religion } \\
\hline Christianity (Ref) & 1.000 & - & & 1.000 & 1.000 & 1.000 & - \\
\hline Islam & 0.852 & - & & 1.634 & $0.475 * *$ & 0.473 & - \\
\hline Traditional & 0.863 & - & & - & 0.720 & - & - \\
\hline \multicolumn{8}{|l|}{ Type of marriage } \\
\hline Monogamous (Ref) & 1.000 & 1.000 & & 1.000 & 1.000 & 1.000 & 1.000 \\
\hline Polygamous & 0.768 & $0.783^{*} *$ & & $0.716 *$ & 0.821 & 0.834 & 1.380 \\
\hline \multicolumn{8}{|l|}{ Household poverty quintile } \\
\hline Poorest quintile (Ref) & 1.000 & 1.000 & & 1.000 & 1.000 & 1.000 & 1.000 \\
\hline $2^{\text {nd }}$ quintile & 1.182 & I. $448 * *$ & & $2.012 * * *$ & 1.973 & 1.335 & 1.408 \\
\hline $3^{\text {rd }}$ quintile & 1.178 & I.804**** & & 2.737 **** & 1.899 & 0.867 & 1.236 \\
\hline $4^{\text {th }}$ quintile & $1.767^{*}$ & $2.432 * * *$ & & $3.435 * * *$ & $2.893 *$ & $1.572 * *$ & 2.233 \\
\hline $5^{\text {th }}$ quintile & $1.957^{* *}$ & $3.166 * * *$ & & 4.105*** & $3.785 * *$ & $1.847^{* *}$ & 2.129 \\
\hline \multicolumn{8}{|l|}{ Relative fertility preference } \\
\hline Want same no. of children (ref) & 1.000 & 1.000 & & 1.000 & 1.000 & 1.000 & 1.000 \\
\hline Husband wants more & 0.892 & $0.54 I^{* * * *}$ & & 0.820 & 0.874 & 0.848 & 0.832 \\
\hline Husband wants less & $1.378 *$ & 0.768 & & 1.021 & 1.569 & 0.966 & 1.363 \\
\hline \multicolumn{8}{|c|}{ Current number of children of woman } \\
\hline More than desired (ref) & 1.000 & 1.000 & & 1.000 & 1.000 & 1.000 & 1.000 \\
\hline Same or less than desired & $0.638 * * *$ & $0.580 * * *$ & & $0.764 *$ & $0.612 * *$ & 1.033 & $0.541 * * *$ \\
\hline \multicolumn{8}{|l|}{ Other controls } \\
\hline Region of residence & Yes & Yes & & Yes & Yes & Yes & Yes \\
\hline Wife's occupation & Yes & Yes & & Yes & Yes & Yes & Yes \\
\hline Husband's occupation & Yes & Yes & & Yes & Yes & Yes & Yes \\
\hline \multicolumn{8}{|c|}{ Summary statistics: } \\
\hline Number of observations & $\begin{array}{l}|49| \\
(52 \%)\end{array}$ & $\begin{array}{c}3999 \\
(30 \%)\end{array}$ & & $\begin{array}{c}1557 \\
(31 \%)\end{array}$ & $\begin{array}{c}1074 \\
(12 \%)\end{array}$ & $\begin{array}{l}1926 \\
(27 \%)\end{array}$ & $\begin{array}{c}692 \\
(20 \%)\end{array}$ \\
\hline Log Likelihood & -841.56 & -1853.07 & & -918.07 & -544.13 & -985.40 & -422.44 \\
\hline Pseudo $\mathrm{R}^{2}$ & 0.0496 & 0.1512 & & 0.1363 & 0.1421 & 0.1460 & 0.1907 \\
\hline Wald Chi-square & 87.64 & 546.46 & & 225.82 & 156.57 & 269.09 & 47.61 \\
\hline$\%$ correctly predicted & $72.84 \%$ & $78.62 \%$ & & $69.49 \%$ & $72.72 \%$ & $75.44 \%$ & $67.28 \%$ \\
\hline
\end{tabular}


Appendix Table B: Results using indicator that woman is in employment that pays cash as measure of bargaining power using later DHS (2008)

\begin{tabular}{|c|c|c|c|c|c|c|c|}
\hline Variable & Ghana & $\begin{array}{c}\text { Burkina } \\
\text { Faso }\end{array}$ & Mali & Kenya & $\begin{array}{l}\text { Mozam- } \\
\text { bique }\end{array}$ & Uganda & Namibia \\
\hline \multicolumn{8}{|c|}{ Woman's earnings from employment } \\
\hline Paid in cash (ref) & 1.000 & 1.000 & 1.000 & 1.000 & 1.000 & 1.000 & 1.000 \\
\hline Not paid/paid in kind & 1.151 & 0.888 & 1.215 & 1.172 & 0.998 & $1.220 *$ & $2.574 * *$ \\
\hline \multicolumn{8}{|l|}{ Woman's education } \\
\hline No education (ref) & 1.000 & 1.000 & 1.000 & 1.000 & 1.000 & 1.000 & 1.000 \\
\hline Primary & $1.463 * *$ & $1.732 * * *$ & I. $745^{* * * *}$ & $2.74 I^{* * * *}$ & $1.539 * *$ & I.667**** & 1.273 \\
\hline Secondary & $1.364 *$ & $2.293 * * *$ & $2.354 * * *$ & $4.384 * * * *$ & $2.518 * * *$ & $3.377^{* * * *}$ & $1.84 I^{*} *$ \\
\hline Higher & 0.537 & $2.27 I^{* *}$ & $3.496 * *$ & $4.049 * * *$ & $2.457^{* *}$ & $2.617^{* * * *}$ & 1.599 \\
\hline \multicolumn{8}{|l|}{ Woman's age group } \\
\hline $15-19$ (ref) & 1.000 & 1.000 & 1.000 & 1.000 & 1.000 & 1.000 & 1.000 \\
\hline $20-29$ & 1.717 & $2.899 * * *$ & $1.616^{*}$ & $2.817^{* * * *}$ & 1.296 & $2.222 * * * *$ & 0.878 \\
\hline $30-39$ & 1.941 & $3.682 * * *$ & $2.7780 * *$ & $3.43 I^{* * * *}$ & 1.487 & $2.4 I I * * * *$ & 0.612 \\
\hline $40-49$ & 1.159 & $2.351 * * * *$ & 0.973 & 1.758 & 0.749 & $2.469 * * * *$ & $0.365^{*}$ \\
\hline \multicolumn{8}{|l|}{ Place of residence } \\
\hline Urban (Ref) & 1.000 & 1.000 & 1.000 & 1.000 & 1.000 & 1.000 & 1.000 \\
\hline Rural & 1.115 & $0.839 *$ & 0.765 & 1.043 & $0.694 *$ & $0.559 * * * *$ & 0.786 \\
\hline \multicolumn{8}{|l|}{ Religion } \\
\hline Christianity (Ref) & 1.000 & - & - & 1.000 & 1.000 & 1.000 & - \\
\hline Islam & 0.850 & - & - & 1.556 & $0.4 I I * * * *$ & $0.283^{* * * *}$ & - \\
\hline Traditional & 0.884 & - & - & - & $0.692 *$ & - & - \\
\hline \multicolumn{8}{|l|}{ Type of marriage } \\
\hline Monogamous (Ref) & 1.000 & 1.000 & 1.0000 & 1.000 & 1.000 & 1.000 & 1.000 \\
\hline Polygamous & $0.698 * *$ & $0.769 * * *$ & 0.920 & $0.751 *$ & 0.924 & 0.887 & 1.062 \\
\hline \multicolumn{8}{|l|}{ Household poverty quintile } \\
\hline Poorest quintile (Ref) & 1.000 & 1.000 & 1.000 & 1.000 & 1.000 & 1.000 & 1.000 \\
\hline $2^{\text {nd }}$ quintile & 1.243 & $1.268 *$ & 0.951 & $2.133^{* * * *}$ & 1.595 & I.294* & 1.173 \\
\hline $3^{\text {rd }}$ quintile & 1.285 & I.39|*** & 0.869 & $2.617^{* * * *}$ & $1.804^{*}$ & 1.155 & 1.062 \\
\hline $4^{\text {th }}$ quintile & I.658* & 2. $124 * * *$ & $1.45 \mathrm{I}$ & $3.045^{* * * *}$ & $2.743^{* * *} *$ & I.51 $7^{* * * *}$ & I.798* \\
\hline $5^{\text {th }}$ quintile & I.899** & $2.607^{* * * *}$ & $2.324^{* * * *}$ & $3.473 * * *$ & $3.832^{* * * *}$ & I.974**** & 1.558 \\
\hline \multicolumn{8}{|l|}{ Relative fertility preference } \\
\hline Want same no. of children (ref) & 1.000 & 1.000 & 1.000 & 1.000 & 1.000 & 1.000 & 1.000 \\
\hline Husband wants more & 0.914 & $0.52 I^{* * * *}$ & $0.726 * *$ & 0.826 & $0.74 I^{* * *}$ & $0.789 * * *$ & $0.720 *$ \\
\hline Husband wants less & $1.465 * *$ & 0.860 & 1.374 & 1.173 & 1.273 & 0.937 & 1.344 \\
\hline \multicolumn{8}{|c|}{ Current number of children of woman } \\
\hline More than desired (ref) & 1.000 & 1.000 & 1.000 & 1.000 & 1.000 & 1.000 & 1.000 \\
\hline Same or less than desired & $0.632 * * *$ & $0.527 * * * *$ & $0.725 *$ & $0.776 * *$ & $0.608 * * *$ & 1.026 & $0.579 * * *$ \\
\hline \multicolumn{8}{|l|}{ Other controls } \\
\hline Region of residence & Yes & Yes & Yes & Yes & Yes & Yes & Yes \\
\hline Wife's occupation & Yes & Yes & Yes & Yes & Yes & Yes & Yes \\
\hline Husband's occupation & Yes & Yes & Yes & Yes & Yes & Yes & Yes \\
\hline \multicolumn{8}{|c|}{ Summary statistics: } \\
\hline Number of observations & $\begin{array}{c}1763 \\
(60 \%)\end{array}$ & $\begin{array}{l}8413 \\
(63 \%)\end{array}$ & 3301 & $\begin{array}{c}2055 \\
(41 \%)\end{array}$ & $\begin{array}{c}2738 \\
(31 \%)\end{array}$ & $\begin{array}{c}3777 \\
(52 \%)\end{array}$ & $\begin{array}{c}937 \\
(27 \%)\end{array}$ \\
\hline Log Likelihood & -962.77 & -3454.85 & -900.82 & -1231.43 & -936.11 & -1834.35 & -579.32 \\
\hline Pseudo $\mathrm{R}^{2}$ & 0.0563 & 0.1424 & 0.1463 & 0.1281 & 0.2180 & 0.1150 & 0.0752 \\
\hline Wald Chi-square & 114.99 & 965.58 & 303.80 & 281.09 & 441.49 & 413.93 & 81.19 \\
\hline$\%$ correctly predicted & $74.48 \%$ & $82.34 \%$ & $90.49 \%$ & $68.32 \%$ & $84.11 \%$ & $77.89 \%$ & $67.28 \%$ \\
\hline
\end{tabular}

